\title{
TERÖRLE VE DİĞER SUÇLARLA MÜCADELEDE KOLLUĞUN SOSYAL MEDYA KULLANIMININ DEĞERLENDİRILMESİ*
}

\author{
Mehmet KAPLAN** \\ $\ddot{\boldsymbol{O}} z$
}

Sosyal medya; düşüncelerin, fikirlerin, deneyimlerin, durumların resim, mesaj ve video gibi iletişim yöntemleri ile paylaşıldiğı, internet tabanlı bir mecradır. Sosyal medyada, medya ve kullanıcıları arasında bir sınır olmadı̆̆ için herkes görüşlerini, fikirlerini, bilgilerini paylaşarak katılım sağlar, katkı yapar ve geri bildirimde bulunur. Bu nedenle kolaylıkla sosyal hareketler planlanarak başlatılır ve yönetilebilir. Sosyal medyanın böyle bir mecra olmasının birçok faydasının yanında güvenlik açısından sakıncaları da mevcuttur. Çünkü paylaşımlar kaynağın amacına yönelik olarak içerisinde zararlı içerikleri de barındırabilmektedir. Özellikle zararlı bilgilerin belli bir denetim süzgecinden geçirilmeksizin paylaşılmasına aracılık etmesi nedeniyle, toplumsal düzen, istikrar ve güvenlik açılarından büyük riskler de taşımaktadır. Teröre karşı mücadelede teknolojinin etkin kullanılması, hak ve özgürlüklerde, güvenlik adına yapılan sinırlandirmaları azaltabilir. Son dönemlerde gelişen teknoloji ile sosyal medya, kolluk kuvvetlerince de etkin olarak kullanılmaya başlanmıştır. Ülkemizde geçmişte terör örgütleri ve suçla mücadelede kolluk kuvvetleri tarafindan internet ve sosyal medyanın kullanımı reaktif bir anlayışla yürütülürken günümüzde ise proaktif anlayışa doğru bir yönelme başlamıştır.

Bu çalışmada terörle ve suçla mücadelede sosyal medyanın kolluk tarafindan kullanılma şekli ile ilgili mevcut durum ortaya konulmuştur. Suçla mücadele etmede ve suçluların tespitinde sosyal medyanın kullanılmasındaki eksiklikler ve ihtiyaçlar nitel araştırma yöntemleriyle incelenmiştir. Görü̈sme yöntemine, özellikle jandarma ve polis teşkilatlarında bilişim suçları ile mücadele kısımlarında çalışan veya çalışmış kişiler dâhil edilmiştir. Elde edilen veriler betimsel analiz metodu ile analiz edilmiştir. Bu çalışma sonucunda elde edilen bilgiler, genel kolluğu oluşturan polis ve jandarmanin terör ve suçla mücadelede sosyal medyayı daha etkin kullanmasına ışı tutabilecektir.

Anahtar Kelimeler: Sosyal Medya, Terör, Suç, Jandarma, Polis,

\section{EVALUATIONS OF THE SOCIAL MEDIA USE BY LAW ENFORCEMENT IN COMBATING TERRORISM AND THE OTHER CRIMES}

\begin{abstract}
Social media is an internet-based medium where thoughts, ideas, experiences, situations are shared with communication methods such as pictures, messages and videos. Since there is no limit between media and users on social media, everyone participates, contributes and gives feedback by sharing their opinions, ideas and information. Therefore, social movements can be easily planned, started and managed. In addition to many benefits of social media being such a medium, there are security drawbacks in many respects as well because the shares may contain harmful contents depending on the aim of the source. It
\end{abstract}

* Bu çalışma 19-20 Eylül 2019 tarihinde Jandarma ve Sahil Güvenlik Akademisi, Güvenlik Bilimleri Enstitüsünde icra edilen Uluslararası Güvenlik Kongresinde sunulan bildirinin genişletilmiş halidir.

** Dr. Öğretim Görevlisi, Jandarma ve Sahil Güvenlik Akademisi, Fakülte Dekanlığı, mehmetkaplan278@hotmail.com, ORCID: 0000-0002-1064-0312 
also carries great risks in terms of social order, stability and security, especially as it mediates the sharing of harmful information without passing through a certain audit. Effective use of technology in the fight against terrorism may reduce the limitation regarding the rights and freedom. Thanks to the recently developing technology social media has started to be used effectively by law enforcement agencies. While the use of internet and social media in the fight against crime and terrorist organizations by law enforcement agencies were carried out with a reactive understanding in the past, a trend towards proactive understanding has started in our country recently.

In this study, the current situation regarding the use of social media by law enforcement agencies in the fight against crime including terrorism was revealed. The deficiencies and needs in the use of social media in the fight against crime and in the detection of criminals were examined through qualitative research method. People who had worked or are still working on cyber-crimes in gendarmerie and police organizations were included in the interview of this study. The data was analyzed with descriptive analysis method which is among the qualitative research methods. The results of this study may shed light on the use of social media in the fight against terrorism and crime by the police and gendarmerie.

Keywords: Social Media, Terror, Crime, Gendarmerie, Police.

\section{GİRIŞ}

Medya, iletişim için bilgisayar ve benzeri diğer mobil cihazların internet üzerinden etkileşimli bir şekilde kullanılmasıyla yeni medyaya dönüşmüştür ve yeni medya internetin bu tarz iletişim gücünü anlatmak için kullanılan bir kavram haline gelmiştir. Yeni medya bu gücü özellikle sosyal medya programları aracılığıyla sağlamaktadır.

Günümüzde bilgiye erişimi ve bilgi paylaşımını kolaylaştırması, olgu, olay ve bilgilerle ilgili tartışma ortamı oluşturabilme ve grup kurma olanağı sunması, üçüncü kişilerin konuyla ilgili paylaşımları anlık takip edebilmesi ve bunlara kendilerinin de katılabilmesine imkân sağlaması gibi özellikleriyle sosyal medya kamuoyu oluşturmada en önemli araçlardan birisi haline gelmiştir. Hatta daha da önemlisi sosyal hareketlerin planlandığ1, organize edildiği, başlatıldığ yönetildiği alanlara dönüşmüştür. Böylelikle birey, toplum ve devlet otoritesi içerisinde, aktif bir konuma sahip olmuştur. Cildan ve diğerleri (2012: 2), sosyal medyanın demokrasi algısını ve uygulamasını, temsili demokrasiden katılımc1 (doğrudan) demokrasiye doğru dönüştürme gücüne ve imkânına sahip olduğunu ifade etmişlerdir. Özellikle Facebook ve Twitter gibi sosyal ağlar, kullanıcılarına tanışma ve mesajlaşmanın ötesinde, organizasyon kurma, organize olma, bilgi ve fikir paylaşma, inanç ve düşünceler etrafında gruplaşma imkânlarını da vermiştir (Boyd ve Ellison, 2008: 213). 
Sosyal medyanın ortaya çıkmasıyla eşik bekçiliği ${ }^{1}$ yapan ve gündem belirleyen ana akım medya kuruluşlarının hegemonyası kırılmaya başlamıştır. Eren ve Aydın, (2014) medyanın içeriğini üreten ve medyayı izleyen arasındaki katı ayrımın ortadan kalktığını, gerçeklerden ziyade fikirlerin önem kazanmaya başladığını ifade etmektedir. Geleneksel medyanın hükümetler tarafından kontrol edilebilir ve sansürlenebilir olması, yayın yasağı konabilmesi sebebiyle, terör örgütleri sosyal medyayı daha fazla tercih eder duruma gelmiştir.

$\mathrm{Bu}$ tercih sebeplerinden birisi de sosyal medya ile internet ortamındaki yaşanan gelişmedir. Bilginin işlenmesi yönünden, tek yönlü paylaşımların oluşturduğu ve Web $1.0^{2}$ olarak adlandırılan internet ortamı dönüşüme uğrayarak Web 2.0 $0^{3}$ denilen ve kullanıcılara internet içeriklerine yorum, bilgi ekleme ve değiştirme olarak katkıda bulunabilme imkânı sağlayan ortama dönüştügü bilinmektedir. Bu süreçte bloglar ve sözlük siteleri sosyal medyanın ilk ürünleri iken zamanla video, ses, zaman, mekân, düşünce ve durum paylaşımının yapıldığg blogların ortaya çıkması ile internet ortamının büyük bölümünü kapsar hale gelmiş ve her geçen gün üye sayılarını arttırarak daha geniş kitlelere erişebilmektedir. Dünyada sosyal medya kullanımının 2014 Mayıs tarihinden günümüze kadar yaşadığı gelişim Tablo 1.'de olduğu gibidir.

2019 Ocak tarihli rapora göre Dünya nüfusunun \%57'sini oluşturan 4,388 milyar insan internet kullanırken \%45'ini oluşturan 3,484 milyar insan aktif olarak sosyal medya kullanmaktadır. Türkiye'de ise nüfusun $\% 72$ 'si internet kullanmaktadır. Her yı1 \%9,3 (5.027.251 kişi) oranında internet kullanımı artmakta olup artış hızı bakımından dünyada 14. sıradadır. Nüfusun \%63’ü (51 milyon kişi) ise aktif olarak sosyal medyayı kullanmaktadır. (https://wearesocial.com/).

\footnotetext{
1 Eşik Bekçiliği (Gatekeeper): Medyanın, haber, yorum, görsel gibi yayınlayacakları içerikleri ekonomi politiğine, yayın kimliğine ve yayın politikasına uygun olarak seçerek yayınlaması, istemediği nitelikteki içerikleri ise yayınlamaması anlamına gelen bir iletişim kuramıdır.

${ }^{2}$ Web 1.0 web sayfalarından oluşan World Wide Web'in ilk aşamasına atıfta bulunmaktadır. Kullanıcılar internet sitelerini ziyaret eder, almak istediği bilgiyi alır ve siteden gider. Yani içeriğe katkıda bulunma veya özgün içerik üretme gibi bir imkânı söz konusu değildir. ( www.bilimcag.com/) ${ }^{3}$ Web 2.0 önceden içerik sağlayıcıların istemcilere cevap vermesi biçiminde tek yönlü işleyen İnternet ortamının biçim değiştirmesi ve tüm istemcilerin aynı zamanda içerik sağlayıcı olabilmesi imkânının sağlanmasıdır. En önemli temsilcileri facebook, flickr gibi sosyal paylaşım ağları, youtube, google video gibi görüntü paylaşım siteleridir. (www.bilimcag.com/)
} 
Tablo-1. Dünyada Sosyal Medya Kullanım Sayıları ${ }^{4}$

\begin{tabular}{|c|c|c|c|c|}
\hline Sirası & Sosyal Ăg & $\begin{array}{c}\text { 2014 Yll (Mayıs) } \\
\text { Uyye Sayısı }\end{array}$ & Sosyal Ăg & $\begin{array}{c}\text { 2019 Yll (Ocak) } \\
\text { Üye Sayısı }\end{array}$ \\
\hline 1 & Facebook & 900.000 .000 & Facebook & 1.500 .000 .000 \\
\hline 2 & Twitter & 310.000 .000 & Youtube & 1.499 .000 .000 \\
\hline 3 & LinkedIn & 255.000 .000 & Twitter & 400.000 .000 \\
\hline 4 & Pinterest & 250.000 .000 & Instagram & 275.000 .000 \\
\hline 5 & Google Plus & 120.000 .000 & LinkedIn & 250.000 .000 \\
\hline 6 & Tumblr & 110.000 .000 & Reddit & 125.000 .000 \\
\hline 7 & Instagram & 100.000 .000 & VK & 120.000 .000 \\
\hline 8 & VK & 80.000 .000 & Tumblr & 110.000 .000 \\
\hline 9 & Flickr & 165.000 .000 & Pinterest & 105.000 .000 \\
\hline 10 & Myspace & 42.000 .000 & Google Plus & 100.000 .000 \\
\hline
\end{tabular}

45 ülkede hizmet sağlayan GlobalWebIndex'in 2019 y1lı sosyal medya raporuna göre 2012 yılından itibaren insanların günlük internet kullanım sürelerini gösteren bilgiler Tablo 2.'de verilmiştir. Buna göre Türkiye 3 saat 5 dakika ile 13 . sırada yer almaktadır. Türkiye'de insanlar $\% 56$ oranında gündemi takip edebilmek için sosyal medyadan haber ve olayları izlemekte ve bu kategoride Filipinler, Malezya ve Tayland'ın ardından dünyada 4. sirada yer almaktadır.

$\mathrm{Bu}$ verilerden, dünya genelinde internet ve buna paralel olarak sosyal medyanın kullanım oranlarının hızlı bir şekilde artmakta olduğu anlaşılmaktadır. Önümüzdeki süreçte bu gelişim hızı ile devam etmesi durumunda dünya üzerindeki insanlara internet ile erişilebilirlik oranları \%90'ları bulacaktır. Bu bize kitle iletişiminde sosyal medyanın gücünü açık bir şekilde göstermektedir.

\footnotetext{
${ }^{4}$ Veriler www.ebizmba.com/ sitesinden temin edilmiştir.
} 
Tablo-2. 2012- 2019 Y1lları Arası Ülkelere Göre Günlük İnternet Kullanım Süreleri (www.globalwebindex.com).

\begin{tabular}{|c|c|c|c|c|c|c|c|c|c|c|c|c|c|c|c|c|c|c|}
\hline & 2012 & 2013 & 2014 & 2015 & 2016 & 2017 & 2018 & 2019 & & & 2012 & 2013 & 2014 & 2015 & 2016 & 2017 & 2018 & 2019 \\
\hline Philippines & $2: 49$ & 3:06 & $3: 25$ & $3: 41$ & 4:07 & 4:00 & $4: 08$ & 4:01 & $\mathbf{a}$ & Singapore & $1: 12$ & $1: 29$ & $1: 36$ & $1: 38$ & $1: 58$ & 2:07 & $2: 11$ & $2: 10$ \\
\hline (2) Brazil & $2: 41$ & $2: 40$ & $2: 50$ & $3: 18$ & $3: 45$ & $3: 40$ & $3: 39$ & $3: 45$ & 든 & USA & $1: 22$ & $1: 34$ & $1: 40$ & $1: 43$ & $2: 04$ & $2: 02$ & $2: 05$ & 1:57 \\
\hline - Colombia & & & & & & & $3: 34$ & $3: 36$ & 0 & Hong Kong & $1: 34$ & $1: 26$ & $1: 27$ & $1: 29$ & $1: 39$ & $2: 00$ & $1: 53$ & $1: 52$ \\
\hline () Nigeria & & . & . & . & . & $3: 03$ & $3: 26$ & $3: 36$ & () & Ireland & & $1: 24$ & 1:11 & $1: 22$ & $1: 38$ & $1: 45$ & $1: 55$ & 1:51 \\
\hline I Argentina & $2: 42$ & $2: 49$ & $2: 50$ & $3: 13$ & $3: 31$ & $3: 12$ & $3: 17$ & $3: 27$ & $\theta$ & Sweden & $1: 13$ & $1: 13$ & $1: 22$ & $1: 33$ & $1: 37$ & $1: 54$ & $1: 49$ & $1: 51$ \\
\hline - Indonesia & $2: 12$ & $2: 21$ & $2: 26$ & $2: 50$ & $3: 02$ & $3: 26$ & $3: 23$ & $3: 15$ & $\theta$ & Taiwan & $1: 28$ & $1: 30$ & $1: 41$ & $1: 50$ & $2: 03$ & $2: 06$ & $1: 52$ & 1:51 \\
\hline C UAE & $2: 21$ & $2: 29$ & $2: 48$ & 3:01 & $3: 24$ & $2: 56$ & $3: 00$ & $3: 11$ & 斗 & UK & $1: 11$ & $1: 14$ & 1:19 & $1: 29$ & $1: 42$ & $1: 54$ & $1: 51$ & $1: 50$ \\
\hline (o) Mexico & $2: 35$ & $2: 50$ & $2: 53$ & $3: 14$ & $3: 33$ & $3: 11$ & $3: 14$ & $3: 10$ & $(\$)$ & Canada & $1: 12$ & 1:29 & $1: 29$ & $1: 27$ & $1: 41$ & 1:48 & $1: 47$ & $1: 49$ \\
\hline 6 South Africa & $1: 58$ & $2: 07$ & $2: 16$ & $2: 42$ & $2: 50$ & $2: 47$ & $2: 58$ & $3: 10$ & v & Poland & 1:02 & $1: 12$ & $1: 13$ & $1: 17$ & $1: 40$ & $1: 42$ & $1: 45$ & $1: 47$ \\
\hline ઈ Egypt & & & & . & $3: 17$ & $3: 06$ & 3:05 & $3: 06$ & () & Italy & $1: 33$ & 1:49 & $1: 47$ & $1: 58$ & $2: 02$ & $1: 53$ & $1: 48$ & $1: 46$ \\
\hline A Kenya & 2.23 & $2: 18$ & $2 \cdot 35$ & 2.55 & $2: 56$ & $2: 50$ & $2: 59$ & $3: 06$ & 궁 & Australia & $1: 15$ & $1: 13$ & $1: 11$ & $1: 10$ & $1: 36$ & $1: 39$ & $1: 34$ & $1: 43$ \\
\hline (2) Turkey & $1: 56$ & $2: 17$ & $2: 25$ & $2: 34$ & $2: 57$ & $2: 49$ & $2: 52$ & $3: 05$ & $\theta$ & New Zealand & & & & & $1: 43$ & $1: 49$ & $1: 42$ & $1: 43$ \\
\hline (3) Ghana & & & & - & - & $2: 59$ & $3: 09$ & $3: 03$ & e & Spain & $1: 30$ & $1: 30$ & $1: 26$ & $1: 38$ & $1: 43$ & $1: 38$ & $1: 41$ & $1: 43$ \\
\hline$\triangleq$ Malaysia & $2: 39$ & $2: 53$ & $2: 48$ & $2: 59$ & $3: 18$ & $3: 06$ & 3:03 & $3: 01$ & \& & Denmark & & & & & & & $1: 35$ & $1: 33$ \\
\hline Thailand & $1: 59$ & $2: 34$ & $2: 41$ & $2: 49$ & $2: 46$ & $3: 06$ & $3: 14$ & $2: 51$ & () & France & 1:01 & 1:05 & $1: 11$ & 1:17 & $1: 23$ & $1: 24$ & $1: 22$ & $1: 28$ \\
\hline ح Romania & & . & & . & . & & $2: 34$ & $2: 28$ & & Belgium & . & & . & 1:15 & $1: 33$ & $1: 31$ & $1: 31$ & $1: 24$ \\
\hline - Russia & $1: 40$ & $1: 46$ & $1: 49$ & $1: 52$ & $2: 17$ & $2: 20$ & $2: 21$ & $2: 28$ & - & South Korea & $0: 47$ & $0: 47$ & $0: 58$ & $1: 05$ & $1: 04$ & $1: 11$ & $1: 11$ & $1: 20$ \\
\hline ₹ India & $1: 44$ & $1: 57$ & 2:03 & $2: 15$ & $2: 30$ & $2: 25$ & $2: 28$ & $2: 25$ & $\approx$ & Netherlands & $0: 56$ & $0: 59$ & $1: 02$ & $1: 10$ & $1: 16$ & $1: 24$ & $1: 17$ & $1: 18$ \\
\hline Morocco & & . & & . & . & $2: 22$ & $2: 34$ & $2: 23$ & $\theta$ & Switzerland & . & & . & - & - & $1: 18$ & $1: 19$ & $1: 18$ \\
\hline ( Vietnam & $1: 47$ & $1: 57$ & $2: 07$ & $2: 16$ & $2: 34$ & $2: 36$ & $2: 33$ & $2: 23$ & $=$ & Austria & . & & . & & & $1: 16$ & $1: 15$ & 1:17 \\
\hline China & $1: 19$ & $1: 17$ & $1: 24$ & 1:27 & $1: 45$ & $1: 58$ & $2: 00$ & 2:19 & $\theta$ & Germany & $0: 58$ & 1:04 & $1: 04$ & 1:08 & $1: 07$ & $1: 13$ & 1:08 & $1: 15$ \\
\hline O Portugal & & . & & $1: 54$ & $2: 13$ & $2: 13$ & $2: 12$ & $2: 18$ & - & Japan & $0: 23$ & $0: 18$ & $0: 17$ & $0: 20$ & $0: 33$ & $0: 46$ & $0: 40$ & $0: 45$ \\
\hline
\end{tabular}

Eren ve Aydın'ın (2014) çalışmalarında ifade ettikleri gibi sosyal medyanın özgürlük alanının bu kadar geniş olması birçok bakımdan iyi olduğu gibi birçok bakımdan da sakıncalar içermektedir. Çünkü hassasiyet arz eden konularda ve insanların yanlış veya kasıtlı yönlendirilmeye müsait olduğu durumlarda ortaya çıkan bilgi kirliliği, kişilere ve topluma zarar verebilecek durumlara yol açabilir. Sosyal medyada dolaşan haberlerin doğru olup olmadığını normal vatandaşın anlık olarak tespit edebilmesi mümkün değildir. Gerçek dışı veya yönlendirilmiş bilginin elde edilmesinden sonra bu insanlara doğru bilgiyi gösterebilme olanağ çok azalmakta, bu olanak sağlansa bile ilk bilginin etkisini azaltmak veya yok etmek imkânsız hale gelebilmektedir. Bu bilgilerle harekete geçen kitleleri durdurmak ya da onlarla sağlıklı iletişim geliştirmek de oldukça zorlaşmaktadır. Bilerek veya 
bilmeyerek, insanlar sosyal medya aracılığıyla yalan veya yanlış bilgileri paylaşarak, kamuoyunda büyük bir bilgi kirliliği ve dezenformasyon oluşturmaktadır. Burada bahsedilen hususların en güncel örneği İstanbul Gezi Parkı eylemlerinde karşımıza çıkmıştır. İstanbul Gezi Parkı olayları 28 Mayıs 2013 tarihinde başlamış, sosyal medya aracılığıyla kısa sürede başta Ankara, İzmir gibi büyükşehirler olmak üzere Türkiye'nin diğer illerine de yayılmıştır. Protestocular eylemlerini duyurma ve organize etmede, toplumu yönlendirmede Facebook ve Twitter başta olmak üzere birçok sosyal medya aracını etkin olarak kullanmışlardır.

"\#OccupyGezi ve \#DirenGeziParki adlı hashtag' formatlarl oluşturulmuştur. 31 Mayıs günü akşam 16:00'dan itibaren 12 saat boyunca konu ile ilgili 3 ana hashtag grubu için 2 milyon tweet atılmuştır. Bunların 950.000'i \#direngeziparkl, 170.000'i \#occupygezi ve 50.000'i \#geziparki'dir. Gezi parkında bekleyenlerin kalabalıklaşmasında ve benzer protestoların çeşitli şehirlere yayllmasında sosyal medyanın etkisi görülmüştür” (Barbera ve diğerleri, 2003).

Ayrıca Avrupa'da da son dönemde benzer olaylar yaşanmıştır. Fransa'da yaşanan sarı yeleklilerin gösterileri; “15 Mayıs 2011'de İspanya'nın 50 farklı şehrinde eş zamanlı olarak başlatılan ve “(Indignados) öfkeliler” olarak anılan grupların eylemleri sosyal medya üzerinden örgütlenip yönetilmiştir” (Eren ve Aydın, 2014). Özellikle Kuzey Afrika ile Ortadoğu ülkelerini kapsayan Arap Dünyasında baş gösteren mitingleri, protestoları, ayaklanmaları ve silahlı çatışmaları ifade eden Arap Baharı, sosyal medyanın kitleler üzerindeki gücünü en iyi şekilde ortaya koymuştur.

Sosyal Medyanın büyük kısmını oluşturan Facebook, Twitter ve Youtube gibi firmalar Tablo-1.'den de anlaşılacağı üzere, özellikle akıllı telefon teknolojisiyle daha geniş kitlelere ulaşma imkânı ve kullanım alanı bularak, pazar paylarını artırmaktadır. "Sosyal medya, güçlü ülkelere diğerlerine karşı, özellikle istihbarat elemanları ve lobiler aracılığıyla eskisinden daha masrafsız ve daha az riskle müdahale olanağı sunmaktadır. Bu amaçla dünyanın herhangi bir yerinden internet üzerinden istenilen provokasyonu başlatmak, sürdürmek ve yönetmek kolaylaşmıştır" (Eren ve Aydın, 2014). Bazı durumlarda ise sosyal medya firmaları

\footnotetext{
5 Sosyal medya kullanıcılarının vazgeçilmez aracı haline gelen hashtag twitter'la birlikte birçok sosyal medya platformuna dâhil olmuş ve hedef kitlelere daha rahat ulaşabileceğimiz bir araç haline gelmiştir. Hashtag adı verilen "\#” diyez işareti; sosyal medyadaki postların daha kolay aranmasını sağlamak için veya belirli bir konudan bahseden bir tweeti etiketlemek için kullanılır. (www. onedio.com)
} 
olayların büyümesini veya gidişatını çeşitli sınırlamalarla engelleyebilmektedir. Örneğin Fransa'daki Sarı Yeleklilerin gösterilerinin şiddetini artırmasıyla "Sarı Yeleklilerin yoğun şekilde kullandığı Facebook mecrası da ilk zamanlardakine oranla tavrını değiştirerek aktif hesapları askıya almaya başlamış" (Özkır, 2018) ve olaylara Fransa Hükümeti lehine müdahalede bulunmuştur.

Sosyal medya bu kadar hızlı gelişerek ve dünyayı kapsayarak gündem belirlemede çok etkin bir araç haline gelmiştir. $\mathrm{Bu}$ gelişen duruma ayak uydurabilmek adına kolluk birimleri de teşkilatlanmalarını değiştirerek sosyal medya birimleri oluşturmuştur. Bu birimler iki farklı boyutta görev yapacak şekilde oluşturulmuştur. Birinci boyutta oluşturulanlar kolluk teşkilatının Halkla İlişkiler ve Tanıtım hedeflerine yönelik çalışmaktadırlar. Diğer boyutta oluşturulanlar ise suçla mücadeleye yönelik görev yapmaktadırlar. Özellikle ilk dönemlerde sosyal medya açık kaynak istihbaratı ${ }^{6}$ amacıyla yoğunluklu olarak kullanılmıştır. Geleneksel gizli yöntemlerin riskli, maliyetli ve zaman alan işlem olması; açık kaynaktan bilgi temininin daha kolay, daha ucuz, daha güvenilir olması ve sosyal medyanın açık kaynak istihbaratında payının artmasına neden olmuştur. Daha sonraki dönemde ise sosyal medya birimleri oluşturularak sosyal medya üzerinde önleyici ve adli kolluk faaliyetleri yürütülmeye başlanmıştır.

$\mathrm{Bu}$ çalışmada "Kolluğun terör ve diğer suçlarla mücadelede sosyal medyayı kullanım durumu nedir ve bu durumu daha iyi bir seviyeye getirmek için neler yapılmalıdır? sorularına cevap aranması amaçlanmıştır. $\mathrm{Bu}$ sorular minvalinde kolluğun sosyal medyadan faydalanarak suçla mücadele etmesindeki mevcut durumu kişisel, kurumsal ve teknolojik bazda ortaya koyarak, eksiklikleri tespit etmek, personel malzeme ve yöntem ihtiyaçlarını belirlemeye çalışarak kolluğa bu alanda katkı sunmaktır. Böylelikle kolluğun suçla mücadele ederken sosyal medya kullanımı konusunda daha proaktif olmasına katkı sağlanabilecektir.

Bu kapsam doğrultusunda çalışmamızda ilk olarak alanda yapılımıs araştırmalar ele alınacak ve bir değerlendirme yapılacaktır. Sonra araştırmamızın modelini, örneklemini ve evrenini, veri toplama yöntemi ile analizini içeren yöntemi ifade edilecektir. Bulgular kişisel, kurumsal ve teknolojik temalar altında değerlendirilerek sonuç kısmı oluşturulacaktır.

\footnotetext{
${ }^{6}$ Açık kaynak istihbaratı herkese açık olan bilgi kanallarından araştırılarak, durumsal farkındalık ile elde edilen ham verilerin çeşitli işlemlerden geçirilerek istihbarat bilgisi haline getirilmesidir.
} 


\section{ALANYAZIN}

Küreselleşmenin ve küresel gelişmelerin etkisiyle terörün ve terörist eylemlerin etkileri ve yayılması tüm dünyada artmaktadır. Teknolojik gelişmeler, iletişim ve ulaşım araçlarını ucuz ve kolay ulaşılabilir hale getirerek, teröristlere eylemlerinde kolaylık ve hız sağlamaktadır. "Terör, Fransızca "terreur" kelimesinden türeyip, aşırı korku ve endişe yaratan özel etkenler ve bireye özgü ussal olmayan ve genellikle bilinçsiz tepkilerin karşıllklı etkileşimi anlamına gelmektedir" (Wilkinson, 2002: 142). Bu nedenledir ki terörist, yaptığı eylemle esasen insan ya da insanları öldürmeyi amaçlamaz. Onun için önemli olan onları öldürdüğü zaman toplumda yaratacağı etkidir (Yalçınkaya, 2008: 4). Terörist eylemler enstrümantal değil de sembolik oldukları için medya aracılığıyla çok çabuk ve etkin biçimde seyredilme, dinlenme ve okunma yoluyla içeride ve dışarıda kolaylıkla gücünü duyurma imkanına sahip olmaktadır. Bu sayede toplumda bir korku halinin ortaya çıkmasından sonra teröristler, toplumun ya da devletin tutum ve davranışlarında değişim ve dönüşüm sağlama isteklerini gerçekleştirebilmektedirler (Wilkinson, 1997). Bununla birlikte “Terörist örgütler eylemli propaganda ile hem kendi grupları içindeki bilişsel alanlarını pekiştirmekte hem de hedef kitle ya da kitleleri etkileyerek kendi fikirlerini benimseterek, grupları dışında da bir bilişsel alan oluşturarak, genişletmeye çalışmaktadır" (Kurum, 2017: 66). Sosyal medya toplumda korkutma ve endişenin en iyi yaratılacağ 1 ortamı sunmanın ve terör örgütlerinin sesini kitlelere duyurmanın en kolay yoludur. Bu sebeple, sosyal medya terörün amacına hizmet eden en uygun araç olarak kabul edilmektedir (Akçay ve Çelenay, 2012). "Terör olaylarının sosyal medyada yer almasının olumsuz yanlarından biri de bu olayların geniş bir kitleye yayılmıs olması ve bu sayede aynı düşünceye sahip kişilerin, olaylara ilişkin yöntemleri, teknikleri öğrenebilmesini ve benzer olayın tekrar etmesine yol açabilmesidir" (Aziz, 1985: 135). Tüm bu açıklamalar 1şığında terör örgütleri açısından sosyal medyanın kullanılmasının en önemli nedenleri Weimann (2004: 3)'in tespitleri ile örtüşmektedir. Bunlar:

- Kolay erişim,

- Büyük bir dinleyici ve izleyici kitlesi

- İktidar sahiplerinin kontrolünün, sansürün, düzenlemenin bu mecralar üzerinde az olması veya hiç olmaması,

- Veri toplama ve bilginin hızlı akışı,

- İletişimin gizliliği, 
- Web varlığının, bakımının ve gelişiminin ucuz olması,

- Multimedya ortamidir.

Weimann (2004: 4) ABD Barış Enstitüsü için 2004 yılında hazırladığı özel rapor için terör örgütlerinin kullandığı internet sitelerini taramış ve şu hususları tespit etmiştir:

- Aktif terörist grupların tümünün internette web siteleri mevcuttur ve teröristler ile destekçilerine hizmet veren yüzlerce web sitesi bulunmaktadır.

- İnternetteki terörizm çok dinamik bir olgudur: web siteleri aniden ortaya çıkar, formatlarını sık sık değiştirir ve daha sonra hızlı bir şekilde kaybolur ya da çoğu durumda, çevrimiçi adreslerini değiştirerek ancak aynı içeriği koruyarak yok olurlar.

- Terörist web siteleri üç farklı kitleyi hedeflemektedir: mevcut ve potansiyel destekçiler, uluslararası kamuoyu, düşman halkı.

DAEŞ terör örgütünün ele alındığı bir çalışmada, örgütün kullandığı hem resmî hem de gayriresmî sitelerinde çoğunlukla da cihat kelimesini ön plana çıkardığı; Youtube, Twitter, bloglar, mesajlaşma sistemleri ve çok sayıda başka platformu kullanarak hem propaganda yaptığ 1 hem de gerçekleştirdiği şiddet eylemlerini sergilediği, böylelikle de istediği konuyu ön plana çıkararak taraftarlarını büyük ölçüde başarıyla harekete geçirebildiği ifade edilmiştir (Kartal, 2018). "DAEŞ sosyal medya sayesinde kendi içine birçok yabancı teröristi çekebilmiştir. Yaptı̆̆ 1 propaganda faaliyetleri ile üyelerini özellikle Müslümanlar arasında model hale getirerek eleman kazanmıştır" (Erdem, 2017). Benzer şekilde Erdin (2017) de aynı örgütün (IŞSiD ismiyle) sosyal medya kullanımını incelemiştir. Görüntüleri istenilen uzunlukta yayınlayabilecek bir alan olmasından dolayı, Youtube'un IŞíD tarafindan tercih edildiğini, Twitter, Youtube ve diğer sosyal medya mecralarına göre belirli bir kişi sayısı ile sınırlı olmasından dolayı Facebook'un daha az kullanıldığını; en yoğun şekilde kullanılan sosyal medya mecrasının Twitter olduğunu tespit etmiştir.

Sosyal medyanın terörizmin yayılmasındaki rolünü ve sosyal medyanın etkilerinin analizini ele alan bir çalışmada Marcu ve Bălteanu (2014) internetin sanal dünyasında aşırılık yanlısı grupların varlığının arttığını, internetteki 10 terörizm vakasının 9'unun sosyal medyaya dayandığını belirlemişlerdir. Buna tedbir olarak ise Amerika Birleşik Devletleri, Kanada ve Büyük Britanya 
askerlerinin kişisel verilerini sosyal paylaşım sitelerinden silmek için eğitildiğini ifade etmişlerdir.

Tunus ve Misır odaklı bir araştırmada, Facebook, Twitter ve Youtube'tan toplanan verilerle, Mısır'daki siyasi web siteleri, Tunus'un tüm blog küresinde gerçekleşen politik diyaloglar ve devrim esnasında gerçekleşen ve filtrelenen 3 milyon tweet değerlendirmesi sonucunda, Arap Baharı'nda sosyal medyanın kritik rolünün olduğu ortaya konulmuştur (Pesen, 2017).

Şu ana kadar belirtilen çalışmalar terör örgütleri ve terörizme yönelik sosyal medya çalışmalarını kapsamaktadır. Bu çalışmalardan farklı olarak Altunbaş (2011) yaptığı bir çalışmada suç ve suçlularla mücadelede polisin sosyal medyadan faydalanma yöntemlerini şu şekilde ana başlıklar altında sıralamıştır.

- Sosyal medyada Polis Merkezi Kayıt Defterinin sergilenmesi,

- Aranan şahısların fotoğraflarının sosyal medya ortamında yayınlanması,

- Polis için geliştirilen web tabanlı bir bildirim araç setinin kullanılması,

- Belirli anahtar kelimeler ve deyimleri kullanarak sosyal medyayı takip etmek,

- Sosyal medya platformlarında çete üyesi gibi davranarak onların içine sızması, böylece çete üyeleri ile onlardan biriymiş gibi irtibata geçerek suç işlenmeden önce önlenmesi,

- Anında bilgi paylaşımı,

- Toplumla iyi iletişim kurulması,

- Suçlularla mücadelede yeni yöntemlerin kullanılması.

Burada belirtilmiş çalışmalardan da anlaşılacağı üzere sosyal medya üzerine yapılan çalışmaların büyük çoğunluğu suçla ve terörle mücadelede sosyal medyanın güvenlik birimleri tarafından kullanımından daha çok gündem belirleme kuramı kapsamında terör örgütlerinin sosyal medyayı kullanmaları üzerinedir. Gündem Belirleme modeline göre insanlar sosyal medya araçlarının değindikleri şeyler hakkında bilgi sahibi olmaya ve farklı konulara verilen önem derecelerini benimsemeye meyilli olacaklardır. Kişiler sosyal medya vasıtasıyla sadece toplumu ilgilendiren konuların ve diğer sorunların neler olduğunu değil; ayrıca, sosyal medya üzerinde verdikleri vurgudan hareketle bir sorun veya bir konuya ne kadar önem vereceklerini öğrenirler. 
Kolluğun sosyal medyadan faydalanmasına yönelik ülkemizde yapılan çalışmalarda (Özçetin ve Özçetin, 2015; Çalı ve Altunbaş, 2012; Arıkan ve Rençber, 2017) ve yurt dışında yapılan çalışmalarda (Chermark and Weiss, 2005; Mostchall and Cao, 2002) odak noktasını kolluğun halkla ilişkiler ve tanıtım bağlamında Facebook, Youtube ve Twitter gibi programları kullanması oluşturmaktadır. Son dönemde yurtdışında suçla ve suçlulukla mücadelede sosyal medyanın kullanımını üzerine araştırmalar ve çalışmalar yoğunlaşmaya başlamıştır. Ülkemizde ise bu konu üzerine yapılan çalışmaların sayısı fazla olmayıp özellikle sosyal medya ile ilgili görev yapan kolluk personelin örneklem olarak alındığı bir çalışmaya rastlanılmamıştır.

$\mathrm{Bu}$ çalışmada amaç; kolluğun suç ve terörle mücadelede sosyal medyayı kullanım durumunu mevcut haliyle ortaya koyarak problemleri ve ihtiyaçları tespit etmektir. Sosyal medyanın kolluk tarafından kullanılması halkla ilişkiler ve tanıtım ile bilgi alma modeli olmak üzere iki şekilde olabilmektedir. Bizim çalışmamızın odak noktasını bilgi alma modeli oluşturmaktadır. Böylelikle elde edilecek verilerin suç ve terörle mücadelede sosyal medyanın kolluk tarafından daha etkin ve verimli kullanılabilmesine yönelik yapılacak çalışmalara 1 şı tutabilmesi amaçlanmıştır.

\section{YÖNTEM}

\subsection{Araştırmanın Modeli}

Sosyal bilimler alanında yapılan araştırmalarda kullanılan en yaygın veri toplama yöntemlerinden biri olan görüşme metodu (Briggs, 1986) bireylerin deneyimlerine, tutumlarına, görüşlerine, şikayetlerine, duygu ve inançlarına ilişkin bilgi elde etmede oldukça etkili bir yöntem olması nedeniyle bu araştırmada tercih edilmiştir. "Görüşme önceden belirlenmiş ve ciddi bir amaç için yapılan, soru sorma ve yanıtlama tarzına dayalı karşılıklı ve etkileşimli bir iletişim sürecidir" (Steward ve Cash, 1985). Görüşme metotlarından ise standartlaştırılmış açık uçlu görüşme yöntemi kullanılmıştır. Bu yöntem "dikkatlice yazılmış ve belirli bir sıraya konmuş bir dizi sorudan oluşur ve her görüşülen bireye bu sorular aynı tarzda ve sırada sorulur" (Patton, 1987: 112) ve "bazı insanlarda daha yoğun ve çok, bazı insanlarda ise daha az sistematik ve yüzeysel bilgi edinilmesine yol açabilecek olan görüşmeci yanlılığını veya öznelliğini azaltır” (Yıldırım ve Şimşek, 2018: 132). 


\section{2. Çalışma Grubu}

$\mathrm{Bu}$ çalışmada amaçlı örnekleme yöntemlerinden faydalanılmıştır. Zengin bilgiye sahip olduğu düşünülen durumların derinlemesine çalışılmasına olanak veren amaçlı örnekleme yöntemleri pek çok durumda, olgu ve olayların keşfedilmesinde ve açıklanmasında yararlı olur (Patton, 1987). Kolluğun sosyal medyayı suçla ve terörle mücadelede kullanmasında yaşanan problemleri bireysel, kurumsal ve teknolojik boyutları yönünden tespit edebilmek için özellikle jandarma ve polis teşkilatlarında görev yapmakta olan 8 personel gönüllülük esasına göre belirlenmiş ve görüşmeler gerçekleştirilmiştir. Örneklemin belirlenen birimlerdeki hizmet yılları ile statüleri farklı olup fikir ve görüş çeşitliliğini sağlayabilmek için standartlık oluşturmamasına dikkat edilmiştir. Görüşmeye katılanlardan bir kişi 5 yıldır bu görevi yapan alana yönelik en tecrübeli kişi iken 4 kişi ise bu görevlere yeni atanmıştır. $\mathrm{Bu} 4$ kişi her ne kadar görevde tecrübesiz gibi gözükse de geçmiş sefahatleri incelenip mülakat sonucu alanda görevlendirildiklerinden, sosyal medya veya internet alanında uzmanlaşmış ve çalışma tecrübesi edinmiş kişiler olarak değerlendirilmiştir. Diğer üç kişinin ise ortalama 3 yıl olmak üzere farklı sürelerde alan tecrübesi bulunmaktadır. Mesleki tecrübe olarak ise ortalama görev süresi 7 yı1 üzeridir. Örneklem sayısı her ne kadar az gibi gözükse de Ankara'da görev yapan jandarma personelinin evreni onsekiz kişidir. Polis evreni biraz daha büyük olmakla birlikte görüşme için gönüllü olan sadece bir kişidir.

\subsection{Veri Toplama Aracı ve Analizi}

Kolluğun sosyal medyayı suçla ve terörle mücadelede kullanmasında yaşanan problemleri objektif olarak tespit edebilmek amaciyla daha esnek imkân sunan yarı yapılandırılmış sorular hazırlanmıştır. Yarı yapılandırılmış görüşme tekniğinin araştırmacıya sunduğu en önemli kolaylık görüşmenin önceden hazırlanmış görüşme protokolüne bağlı olarak sürdürülmesi nedeniyle daha sistematiktir. Görüşme odaklı yapılan nitel çalışmada veriler aşağıda belirtilen yarıyapılandırılmış görüşme soruları aracılığıyla toplanmıştır.

- Ne zamandır bu görevi yapıyorsunuz?

- Suçla ve terörle mücadelede sosyal medyayı nasıl kullanıyorsunuz?

- Gerek teknolojik gerekse diğer hususlarla ilgili yaşadığınız sorunlar nelerdir?

- Suçla ve terörle mücadelede sosyal medyanın daha iyi kullanılabilmesi için sizce başka neler yapılabilir?

- Bu hususlar haricinde kolluk olarak sosyal medyadan nasıl faydalanabiliriz? 
Görüşmelerde aşağıdaki hususlara dikkat edilmiştir.

1. Görüşme öncesi katılımcılara araştırmanın amacı açıklanmıştır.

2. Görüşme soruları tüm katılımcılara belli bir sıra dâhilinde ve değişiklik yapılmadan sorulmuştur. Bu sorulara verilen cevapların durumuna göre ilave sorularla konu derinliği oluşturulmaya çalışılmıştır.

3. Görüşme esnasında ses kaydı oluşturulmuş, katılımcıların ifadeleri kayıt cihazına kaydedilmiştir. $\mathrm{Bu}$ kayıtlar tüm görüşmeler tamamlandıktan sonra görüşme formlarına kaydedilmiştir.

4. Katılımcıların düşünce ve ifadelerini etkileyebilecek söz, jest, mimik ve diğer bireylerin olmamasına dikkat edilerek, objektif açıdan cevapların alınmasına özen gösterilmiştir.

Daha önce benzer bir çalışma yapılmadığı için sorular belirlenmiş ve bu sorular araştırma alanında görev yapan kişilere gösterilerek yeterli olup olmadığı, ilave soru gerekip gerekmediği, soru tarzında değişim yapılmasına ihtiyaç duyulup duyulmadığı sorulmuş ve ortak görüş olarak yeterli olduğu ve herhangi bir değişim gerekmediği belirtilmiştir. Ayrıca ilave sorular görüşülen kişilerin kapalı cevaplarını daha açık hale getirmek amacıyla sorulmuş olup ana soru niteliği taşımadığı için metne dâhil edilmemiştir.

Araştırmada elde edilen veriler üç tema altında toplandıktan sonra betimsel analiz tekniğiyle çözümlenmiştir. "Betimsel analiz, çeşitli veri toplama teknikleri ile elde edilmiş verilerin daha önceden belirlenmiş temalara göre özetlenmesi ve yorumlanmasını içeren bir nitel veri analiz türüdür. $\mathrm{Bu}$ analiz türünde temel amaç elde edilmiş olan bulguların okuyucuya özetlenmiş ve yorumlanmış bir biçimde sunulmasıdır" (Yıldırım ve Şimşek, 2018: 239). Bireylerin görüşlerini çarpıcı bir biçimde yansıtabilmek amacıyla doğrudan alıntılara yer verilmiştir. Kolluğun sosyal medya kullanımında etken olabilecek hususlar ele alınmış ve yapılan ön değerlendirme sonucu sorunsalımıza etki edebilecek hususların kolluk personelinin kişisel özellikleri, kolluk teşkilatı ile sosyal medya araçlarının oluşturduğu kurumsal özellikler ve alanın doğası gereği teknolojik özellikler olmak üzere üç tema belirlenmiştir. $\mathrm{Bu}$ doğrultuda katılımcıların sorulara verdikleri cevaplar benzerliklerine göre gruplandırılarak, yorumlanmıştır.

\section{BULGULAR}

$\mathrm{Bu}$ araştırmanın bulguları üç tema altında toplanmıştır. $\mathrm{Bu}$ üç tema; kişisel özellikler içeren, kurumsal özellikler içeren ve teknolojik özellikler içeren tespitler olarak sınıflandırılmıştır. Görüşmeye katılan kişilerin tamamı jandarma ve polis teşkilatlarında suçla ve terörle mücadelede sosyal medya veya internetin 
kullanıldığı bilişim veya siber kısımlarında aktif olarak görev yapmaktadır. Tüm katılımcıların görevdeki hizmet yılları farklı olmasına rağmen görüşlerinin birbirleri ile örtüştüğü anlaşılmıştır.

\subsection{Kişisel Özellikleri İçeren Tespitler}

Avşar (2017)'ın ifade ettiği gibi sosyal medya, istihbarat örgütleri ve istihbarat toplayan kurumların bilgi toplaması ile hedef kişilerin tespit edilmesi için geniş bir alandır. $\mathrm{Bu}$ yolla kişiler, kurumlar, ülkeler hakkında kolayca bilgiye ulaşılabilmektedir. Özellikle Korkmaz (2013)'ın da çalışmasında ele aldığı Facebook, program yapısı itibariyle kişilerin okulları, mesleği, arkadaşları, hobileri, ilişki durumları gibi kişisel bilgilerinin bile kişinin isteği doğrultusunda deşifre eden bir sosyal mecradır. Terör örgütlerinin kullandığı gibi kolluk mensupları da suç işlediği anlaşılan veya terör örgütü mensubu olduğu düşünülen kişileri arkadaş olarak ekleyerek kişisel bilgilerini, (adı, soyadı, fotoğrafları, çalıştığı yer, mezun olduğu okullar, dini ve siyasi düşüncesi, ilgi alanları, vb.) arkadaş listesini, oturduğu şehri, şu anda nerede olduklarını, o anki ruh durumlarını, ülke siyaseti ya da gelişmeler hakkındaki düşüncelerini kolaylıkla öğrenebilirler.

Sosyal medyada milyonlarca kişi ve grup sayısız bilgi ve düşünceyi anlık olarak ve sürekli paylaşmaktadır. Katılımcılar, bu kadar bilginin arasından kolluk açısından faydalı olan bilgileri tespit etmenin ve devşirmenin kolluk personelinin dikkatine, yeteneğine, aldığ 1 kurs ve eğitimlerin sonucu oluşan bilgisine bağlı olduğunu bildirmiştir. Ayrıca katılımcıların genel görüşüne göre, kurumların bu görevlere tahsis ettikleri kişi sayısı çok yetersizdir. Bu nedenle bu kişilerin alanda yeterli bilgiye sahip ve gerekli kursları görmüş kişiler olması gerekmektedir. Buradan anlaşılacağı üzere çalışacak personelin belirlenmesinde özellikle alanla ilgili bilgi ve tecrübe altyapısı ile kişisel bazı kriterlerin (dikkat, durumsal farkındalık, araştırmacı kişilik vb.) aranması gerekmektedir.

“Şu anda tamamen personel dikkatine bağll performans yürütülmekte.” (A-1/A)

"Kaliteli personel seçimi yapılması lazım. Bu alanda iyi bir personelin yetiştirilmesi için uzun zaman gerekiyor. Şu anda adli bilişim uzmanları 6 farklı program kullaniyor, imajları alyyorlar. Bunu yapa yapa daha çok kendilerini geliştiriyorlar. Kendini geliştiren personel klsa zamanda daha çok iş ortaya çıkarıyor." (A-2)

"paylaşımlardan kişinin dikkatine bağlı olarak da tespit yapabiliyoruz, bu tamamen kişinin dikkatine bağll." (A-3) 
Sosyal medya tamamen teknolojiye bağlı olup gelişimi yaşayan bir süreçtir ve bu süreç durmadan devam eder. Katılımcılar, alanda yetişen personelin meslek hayatı boyunca aynı görevleri yapmasının verimliliği artıracağını, aksi takdirde ise kaynak israfı olacağını bildirmişlerdir. $\mathrm{Bu}$ durum alanda çalışan personelin de sürekli kendisini geliştirmesini zorunlu kılmaktadır. Gelişimi takip edemeyen ve performans kaybı yaşayan kişilerin alan dışına çıkarılması kaynak verimliliği açısından önemlidir.

"Siber ve Adli Bilişim alanında çalışan bir personel tayin olduğunda gittiği yerlerde de aynı görevlere devam etmesi gerekiyor. Alan devaml gelişiyor, hep yeni şeyler çıklyor. Personel ara verdiği zaman, bir yıl ara verse, sıfirdan tekrar başlamak zorunda kalır. Bu iş uzun süren ve sürekli devam ettirilmesi gereken iş." $(A-2)$

Yazılım ve donanım ana başlıkları altındaki birçok alt alanda çok hızlı bir teknolojik gelişim söz konusudur. Sosyal medyanın suçla mücadelede kullanılabilmesi için gerekli olan asgari bilgisayar kullanım bilgisi çok fazla insan gücü ve zaman gerektirmektedir. Personelin verimli çalışması için günümüzün şartlarına göre sürekli kendisini geliştirmesi gerekmektedir. Personel her ne kadar kendisini geliştirmeye gayret gösterse bile bilişim alanındaki bu yeniliklerin hepsine vakıf olması çok zordur. Bu nedenle alanda daha etkili olabilmek için personel haricinde, kurum dışı kaynaklardan sosyal medya uzmanları, yazılımcılar gibi uzman kişilerden destek alınmasına ihtiyaç duyulabilmektedir. Kurum dışından bu tarz kişilerin temin edilebilmesi ve çalıştırılabilmesi için gerekli düzenlemelerin yapılması gerekmektedir.

“Konuyla ilgisi ve bilgisi olan yazllım mühendisleri alınabilir..." (A-1)

Dünyaya hâkim olan ve kullanım yönünden ana payı oluşturan Facebook (www.sosyalmedya.co), LinkedIn'i alan Microsoft ve Youtube'u alan Google (www.haberturk.com) gibi sosyal medyanın patronları veya merkez ülkeleri Anglosaksondur. Bu nedenle diğer alanlarda olduğu gibi bu alanda da İngilizce hakimiyeti söz konusudur. Bilişim kısımlarında veya sosyal medyada araştırma yapacak ve kullanacak personelin İngilizce bilmesi artı değer katmaktadır.

“Bu şubede çalışan personelin kesinlikle İngilizce bilmesi gerekiyor.” (A-2)

"Personelin eğitimli olması gerekiyor. İnternette ne aradĭ̆ını bilen personel daha iyi mücadele eder; bazı personel suçları ve ne aradığını bilmiyor.” (A-6) 


\subsection{Kurumsal Özellikleri İçeren Tespitler}

1989 yılında www'nin (world wide web) kullanıma başlaması ve 1990'lı yılların sonunda ilk blogların ortaya çıkması ile sosyal medya kavramı ortaya çıkmıştır. 2004 yılından itibaren ise Facebook, Youtube, Flicker ve Twitter gibi sosyal ağların kurulması ile büyük bir gelişim göstermiştir. Türkiye'de ilk internet bağlantısı 12 Nisan 1993 tarihinde ODTÜ tarafından yapılmıştır. Sosyal medya kullanımı ise dünya geneliyle paralel gitmiştir.

Tüm dünyada olduğu gibi ülkemizde de güvenlik kuvvetleri siber terörizm ${ }^{7}$ tehdidine karşı aşırı hassasiyet göstermektedir. Buna karşın, internetin günlük ve rutin kullanımlarına yeterince dikkat edilmemektedir. Halbuki teröristler ve suçluların propaganda ve psikolojik savaş, kaynak ve eleman temini, veri madenciliği ve eylemlerin koordinasyonu gibi faaliyetlerini internetin günlük ve rutin kullanım alanlarında gerçekleştirdikleri görüşmelerin ortak noktası olarak tespit edilmiştir.

Kolluğun siber suçlarla mücadele amaçlı kuruluş tarihçesi Tablo 3.'de verilmiştir. Kuruluş kronolojileri kolluğun internet ve sosyal medya araştırma ve kullanım durumunun gelişimini de ortaya koymaktadır.

Tablo-3. Kolluğun Siber Suçlarla Mücadele Amaçlı Kuruluş Tarihçesi ${ }^{8}$

\begin{tabular}{|l|l|l|c|}
\hline \multicolumn{2}{|c|}{ Jandarma } & \multicolumn{2}{c|}{ Polis } \\
\hline Bilişim Suçları Kısmı & 2004 & $\begin{array}{l}\text { İnternet Suçları ile Mücadele } \\
\text { Amirliği }\end{array}$ & 1997 \\
\hline Bilişim Suçları Şube Müdürlüğü & 2009 & Bilişim Suçları Çalışma Grubu & 1999 \\
\hline $\begin{array}{l}\text { Siber Suçlarla Mücadele Daire } \\
\text { Başkanlığ1 }\end{array}$ & 2019 & $\begin{array}{l}\text { Bilişim Suçları Araştırma } \\
\text { Merkezi }\end{array}$ & 2000 \\
\hline & & $\begin{array}{l}\text { Bilişim Suçlarıyla Mücadele } \\
\text { Daire Başkanlığı }\end{array}$ & 2011 \\
\hline
\end{tabular}

Kolluk internet ve sosyal medya aracılığ ile suç araştırma görevlerini bilişim ve siber kısımları ile istihbarat birimleri aracılığıyla yerine getirmektedir. Suç ve suçlularla mücadelenin ana yükünü çeken asayiş birimleridir. Suç ve terörle mücadele eden kolluğun günümüz teknoloji çağının gereği olarak her an internete ve sosyal medya sitelerine erişimi olmalıdır. Katılımcılar asayiş birimlerinde çalışan personelinin internet ortamında birçok programa erişim sağlayamadığını

\footnotetext{
${ }^{7}$ Belirli bir politik ve sosyal amaca ulaşabilmek için bilgisayar veya bilgisayar sistemlerinin bireylere ve mallara karşı bir hükümeti veya toplumu yıldırma, baskı altında tutma amacıyla kullanılmasıdır (Özcan, 2002: 309).

8 Jandarma Genel Komutanlığı ve Emniyet Genel Müdürlüğünden temin edilmiştir.
} 
belirtmişlerdir. Buna ilave olarak özellikle bilişim suçlarında görevli personelin tüm sitelere erişim izninin olması, hatta mahkeme kararlarıyla yasaklanan sitelere de girilebilmesi için düzenleme yapılması gerektiğini ifade etmişlerdir.

Kolluğun kullandığı internet hattı kurumsal internet hattıdır. Bilişim suçlarına bakan, internet ve sosyal medya ortamında araştırma yapan ve soruşturma için delil toplayan kolluk personelinin kullandığı internet hattının kurumsal olmasının bazı sakıncalarının bulunduğu tespit edilmiştir. Suç veya terör örgütleri içerisine girerek bilgi toplamaya çalışan kolluğun kullandığı internet IP adresi, örgüt elemanlarından bilgisayar kullanım bilgisi iyi olan kişilerce tespit edilebilmektedir. Kolluğun internet hattı olduğunun anlaşılması üzerine örgüt mensupları tarafından ilgili kolluk personeli sanal ortamda engellenerek veya gruba üyeliği iptal edilerek araştırma veya soruşturma çabaları sekteye uğratılmaktadır. Buna ilave olarak takip edilen bir olayda suç örgütü üyeleri böyle bir durum karşısında işleyecekleri bir suçun plan ve icrasında değişikliğe gitmektedir. Bu da kolluğun bu suça yönelik toplamış olduğu tüm bilgilerin boşa çıkmasına neden olmaktadır.

“...birçok siteye erişim izinle yapılmaktadır. Biliş̧im kısmı olarak erişimlerimiz mevcuttur ama diğer personelin böyle erişim izni yoktur. Erişimlerimiz olsa bile kurumsal ăgdayız ve hareket kabiliyetimiz çok kısıtll. Kurum ă̆ında çalıştı̆̆ımızdan dolayı suç örgütleri ile iletişime geçtiğimizde karşıdaki insanın biraz bilgisayar bilgisi mevcutsa benim bă̆landı̆̆ım ă̆ı göreceğinden dolayı iletişimi keser. Bize bă̆ımsız bir internet kesinlikle şart.” (A-1)

"Kullandiğımız internet hattı kurumsal hat olduğu için grupları kuranlar bizim ... olduğumuzu anliyor ve bizi gruplara almiyor, engelliyorlar." (A-5)

Sosyal medya firmaları ticari çıkarları doğrultusunda üyelerinin bilgilerini paylaşmak istememektedirler. Bunun içinde her türlü firsatı değerlendirerek bilgi taleplerini karşılamamaktadırlar. Çocuğun cinsel istismarı ve uyuşturucu ticareti gibi suçlarda bilgi paylaşan bu firmalar diğer birçok suçta talepleri reddetmektedirler. Terörist gruplar ve suç örgütlerinin sosyal medya ortamını kullanmaları veya çocuk pornosu, uyuşturucu, işkence, cinayet gibi bazı suçların sosyal medyada yer alması durumunda bu kullanımın kisitlanmasi, hesapların dondurulması, bu konulara yönelik yapılan soruşturma veya kovuşturmalarda istenilen bilgilerin ilgili makamlara verilmesine imkân sağlayacak, insanların mahremiyet ve medeni özgürlükler üzerindeki haklarının da teminat altına alacak, hukuki mevzuatın sosyal medya firmaları ile oluşturulması gerekmektedir. 
'Facebook veya Twitter'dan bir şey talep ettiğimizde bunun bize dönüşü her zaman olumlu olmuyor. Resmi olarak sosyal medya firmalarindan talep edildiğinde bize bilgi verilmiyor. Türkiye'de temsilcilikleri var, fakat bizimle bilgi paylaşımı yapmıyorlar. Cinsel istismar gibi bazı konularda bilgi veriyorlar ama diğer konularda geri dönüş olmuyor. Terör konusunda bilgi paylaşımı yapılmıyor." (A-3)

"Firmaların İstanbul'da büroları var. Bilgi talep ediyorsunuz. Hiçbir şey vermiyorlar." A-2

Medya halkı bilgilendirmek ve bilinçlendirmek için devletin kullanabileceği önemli güçlerden biridir. "Yalan yanlış bilgilerle halk arasında endişe yaratmak isteyen terör örgütlerine hizmet eden fisıltı gazetelerinin emelleri ve dedikoduları, yine halka doğru bilgiler verilerek, boşa çıkarılabilir. Bunun yanı sıra, medyada yer alan terör haberleri, terörün verdiği zararları ve ülke üzerindeki olumsuz etkisini ön plana çıkararak, halkın teröre karşı daha fazla kenetlenmesini sağlayabilir." (Kazan, 2016: 128). Bu gücün farkında olan Jandarma ve Polis Teşkilatı halkla ilişkiler ve tanıtım kapsamında kurumsal sosyal medya sitelerini kurmuş olup bu siteleri aktif olarak kullanmaktadırlar.

Katılımcılar, toplumsal olay, gösteri ve eylemlerin engellenmesinde veya etkisinin azaltılmasında personelin kişisel paylaşımlarının çok fazla etkisinin olmayacağını değerlendirmektedir ve bilgi kirliliğinin önüne geçilebilmesi, provokasyona maruz kalmaların engellenebilmesi ve eyleme katılım oranının azaltılabilmesi için Jandarma ve Polis ile Valilik sosyal medya hesaplarından yapılacak paylaşım ve bildirimlerin daha etkili olacağı kanısındadırlar. Bu tarz kriz durumlarında sosyal medya hesapları halkla ilişkiler ve tanıtım amacından ziyade gündem belirleme modeli olarak kullanılabilecektir. Bu doğrultuda kolluğun sosyal medya sitelerinin takipçi sayılarını artırmak için çalışmalar yapılmalıdır. Bilhassa Halkla İlişkiler faaliyetlerinde sosyal medyaya daha fazla ağırlık verilmelidir.

"Bizim paylaşım yaparak toplumun yönlendirilmesini engellememiz zor. Bunun yerine kurumsal hesaplar Jandarma, Polis, Valilik gibi buralardan resmi bilgi paylaşımı yapılarak engellenmeye çalışılmalıdır ki bu daha etkili olacaktır." (A-3)

"Özellikle yaptığımı faaliyetler ile ilgili reklam yapmaya ihtiyacımız var. Bunu sağladığımız takdirde insanlar ister istemez bu konularla ilgili bizlere ihbarda bulunacaklardır. Böylece iş döngümüz artacaktır." (A-7)

"Öncelikle yapılan faaliyetlerin reklamı yapılması gerekiyor hem kurumun adını duyurmak hem de caydırıcı bir etki bırakmak için." (A-4) 


\subsection{Teknolojik Özellikleri İçeren Tespitler}

Günümüzde teknoloji çok hızlı bir şekilde ilerliyor. 1989'da başlayan internet Web 1.0 olarak adlandırılırken sosyal medyanın da dâhil olduğu Web 2.0'a dönüşmüş, arkasından çok kısa bir sürede yapay zekanın rol oynadığı Semantik Web denilen Web $3.0^{9}$ çağ hıza kolluğun da ayak uydurması gerekmektedir. Bunu yapabilmesi için de güncel programlar ve bilgisayar sistemleri kullanılmalıdır. Kolluk insan kaynağının çok az bir kısmını bu mücadeleye ayırabilmektedir. Bir kişinin günlük 8 saat mesai yaptığı göz önünde bulundurulduğunda bilgisayar karşısında dikkatini kaybetmeden yapacağ 1 araştırma süresi 8 saatten daha azdır. Kişinin tüm mesaisinde bilgisayar karşısında inceleme yaptığ 1 kabul edilse bile gün boyunca bir alanda en az 3 kişinin görev yapması gerekir. Binlerce alan olduğu düşünülürse bu incelemeler için insan kaynağı yetersiz kalır. $\mathrm{Bu}$ nedenle güncel tarama ve analiz programlarının kullanılması sosyal medyada suç ve terörle mücadelede kaçınılmaz hale gelmiştir.

"Milyonlarca paylaşımı analiz etmeniz ve incelemeniz kişisel olarak çok zor. Bunlar bir programla yapmak her zaman daha kolay oluyor." (A-3)

“İternet üzerinde kullanılan ... programlar şu anda paralı hale gelmiştir. Bu da araştırmalarınızı zorlaştırmaya başlamış̧ır. Yeni programların alınmasıyla suçla ve suçluyla mücadelede daha iyi çalışacağımıza inanıyorum." (A-6)

“....sosyal medya sitelerinde tarama yapan programlar mevcut. Bu programlar sayesinde Türkiye'de ve dünyada yapılan paylaşımları tarayarak girdiğimiz anahtar kelimeleri tarayarak tespit eden programlar var." (A-1)

"Siz insan olarak 8 saat takip edebilirsiniz ama 24 saat takip edemezsiniz. 24 saat esasına göre çalışan değişik programlar var; sizin vermiş olduğunuz kod kelimelerle süzme işlemi yaparak size rapor çıkaran programlar kullanılması gerekiyor." (A-2)

\footnotetext{
9 "Web 3.0 içerik kontrolünün yazılımların eline geçtiği bir dünya olarak adlandırılabilir. Birbiriyle iletişim halinde olan veritabanı sistemleri sayesinde nelerden hoşlandığımızı anlayabilen ve buna göre bizlere çözüm sunan bir Web sistemidir. Web 3.0, eski hali Web 2.0'1n sanal dünyaya aktardıklarını anlamlandıran bir 'Yapay Zeka' olarak adlandırılır hale gelmiştir." (www.bilimcag.com/ para. 7)

10 "Web 4.0, en kapsamlı ve kişiselleştirilmiş, sadece bilgileri görüntülemekle sınırlı olmayan, ancak kullanıcının ihtiyaç duyduğu şeylere somut çözümler sunan akıllı bir ayna gibi davranmayı öneren yeni bir kullanıcı etkileşimi modeli sunar." (www.prezi.com/ Elekoğlu, WEB 4.0 Nedir?)
} 
Teknolojinin güncel tutulabilmesi için yapılacak yazılımsal ve donanımsal alımlar veya ihalelerin sürelerinin kısa olması gerekmektedir. Mevcut ihale kanunu ile yapılan alımlarda süreç altı ay veya daha fazla sürebilmektedir. İhalesi yapılan sistemler en son teknoloji ürünü iken bu süreç esnasında daha hiç kullanılamadan güncelliğini yitirebilmektedir. Ayrıca kurum dışından, ihtiyaç halinde, program yazılımcısı ve donanımcı insan gücü temin edilebilmelidir. Bu kişiler vasıtasıyla teknoloji güncel k1lınabilir. Gerektiğinde alana yönelik eğitim faaliyetleri ve kurslar ile kurum personelinin bilgilerinin güncelliği sağlanabilir, ihtiyaç duyulan alanlarda eksiklikleri tamamlanabilir.

“Güncel yazılımların olması gerekiyor ve bu yazılımlarla ilgili kurslar verilmesi gerekiyor.” (A-4)

"Ihaleye çıklan bilgisayar sistemlerinin alınması biraz daha kolay olması gerekiyor." (A-6)

Bazı katılımcılar sosyal medya üzerinden yapılan araştırma ve operasyonlar sayesinde yakalanan faillerin kitle medyasında yer almasının terör ve suç örgütü üyelerini başka mecralara yönlendirmeye başladığını bildirmişlerdir. Bunlardan bazıları online oynanan oyunların mesajlaşma bölümleridir. Bir diğer yöntem ise deepweb ortamlarıdır. Bu nedenle kolluk internet içerisinde devamlı araştırmacı ve yaratıcı düşünce ile sanal devriyesini icra etmek zorundadır. Suçluların veya teröristlerin kimliklerini gizlemek için kullandıkları bir yöntem de VPN ${ }^{11}$ (Virtual Private Network) Sanal Özel Ağ'dır. En temel anlamıyla internete başka bir IP adresi üzerinden bağlanmanızı sağlayan hizmettir. VPN, bağlantınızı güvenli hale getirir ve herhangi bir ağa bağlanırken sizin bağlantınızı şifreler ve kimliğinizin bulunamamasını sağlar. Kolluk internet ortamında, suçla ve terörle mücadele ederken sadece sosyal medya ile sınırlı kalmamalı ve internetin diğer alanlarına yönelik çalışmalar da yapacak şekilde yapılanmalıdır.

\footnotetext{
${ }^{11}$ Genellikle iş ortamı dışında yapılan bağlantılarda iç ağdayken sahip olunan yetkilerin dış ağdayken de devam etmesini sağlamayı amaçlayan bağlantı türüdür. Bunu gerçekleştirmek için noktadan noktaya bağlantı tekniği ve bu bağlantı sırasında da verilerin kapsüllenmesi yöntemi kullanılır (Baykal 2001'den akt. Erol, 2019)
} 


\section{SONUÇ}

Teröristler ile suçlular kıyaslandığında sosyal medyanın kullanım amaçlarında farklı1ıklar bulunmaktadır. Teröristler sosyal medyayı gündem oluşturma kuramı çerçevesi içerisinde eylemlerini duyurmak, propaganda yapmak için kullanırken diğer suçlularda böyle bir düşünce yoktur. Bununla birlikte suçluların büyük bir çoğunluğu sosyal medyayı farklı amaçlar için kullanabilmektedir. Bunlar genelde iletişim kuramlarından Westley-Maclean Aracılanmış İletişim Modeli ile çok örtüşen bir yöntem oluşturmaktadır. Burada bariz bir farklılık varsa o da aracılık yapanların çoğu bunu kasıtlı aracılık şeklinde yapmalarıdır. Suç örgütleri veya suçlular diğer suçlularla iletişim kurmak veya irtibat sağlamak, kaçakçılık suçunu teşkil eden malzemelerin tanıtımını ve pazarlamasını yapmak; suç işlemeden önce suçun işlenme yöntem ve teknikleri hakkında bilgi almak, suç işlemeden önce yanlış ve yalan bilgiler kullanarak suç ortamını sağlamak amaçlarıyla bu iletişim yöntemi ile sosyal medyayı kullanmaktadırlar.

Bunun yanında kolluk personeli ise suçla ve suçlularla mücadelede sosyal medyayı bilgi arama modeli kapsamında kullanmaktadır. Bunun kolluktaki karşılığı kısmen açık kaynak istihbaratı olarak ifade edilebilir. Açık kaynak istihbaratı gizli istihbari faaliyetlerden başka yöntemlerle toplanan bilgiler olarak kabul edilir ve kitle medyasının gelişmesi ile önemi de artmıştır. Sosyal medyanın açık kaynak istihbaratında payı da artmaktadır. Açık kaynak bilgisini bulmak daha kolay, daha ucuz ve daha güvenilirdir. Açık kaynaklardan elde edilen bilgiler ile diğer istihbari faaliyetler yönlendirilebilir ve maliyetleri azaltılabilir.

$\mathrm{Bu}$ amaçla sosyal medyayı kullanacak personel istihdam etmek verimlilik ve etkinlik açısından yeterli olmayacaktır. İstihdam edilecek personelin kolluk tecrübesi yanında bilgisayar altyapısı olan, sosyal mühendislik yetenekleri gelişmiş, mümkünse İngilizce bilen kişiler arasından seçilmesi etkinlik ve verimliğin sağlanması için ana unsurlardır. Bu seçimle sağlanan verimliliğin daha ileri seviyeye çıkarılması için gerekli kurs ve eğitimlerle personelin yetiştirilmesi gerekmektedir. $\mathrm{Bu}$ personelin sürekli değișen sosyal medya formları hakkında bilgilerini güncel tutması sağlanmalı ve kurum içindeki atamalarda personel bu görevlerini aralıksız sürdürebileceği kadrolara atanmalıdır. Böylece özellikle suç örgütlerinin kullanmış oldukları ve Westley-Maclean Aracılanmış İletişim Modelinde sözü geçen özellikle kasıtlı aracıların tespitinde daha tecrübeli olacakları ve verimli çalışabilecekleri değerlendirilmektedir. 
Bunun yanında mevcut durum olarak personelin genel itibariyle niteliksel olarak yeterli olmasına rağmen niceliksel olarak yeterli olmadığı tespit edilmiştir. Gelişen teknolojik altyapı ile sosyal medyanın kapsamı ve içeriğinin gittikçe büyüdüğü göz önünde bulundurulursa personel istihdamında bir ivmeye ihtiyaç duyulacağı açıktır.

Terör ve suç örgütleri üyeleri sosyal medya hesaplarının takip edildiğini ve bu vasıtayla bazı faillerin yakalandığını bildikleri için eylem organizasyonu ve iletişim için başka mecralara yönlenmişlerdir. Bu mecralar online oyunların içinde bulunan mesajlaşma eklentileri veya oyun forumlarıdır. Oyunların içindeki mesajlaşma yöntemlerinde grup veya ittifak oluşturularak yapılan haberleşmeler diğer oyunculara kapalı olmakta ve istenilen şekilde bilgi alışverişi yapılabilmektedir. Başka bir yöntem olarak ise VPN programları kullanılarak internete bağlanılması veya Deepweb alanında faaliyet yürütülmesidir. Bu alanda araştırma ve soruşturma yürüten personel gerek teknolojinin gelişimi ile ilgili gerekse suçluların yeni yol ve yöntemleri ile ilgili daima bilgilerini güncellemelidir. Bu güncellemeyi yapamayan ve kendini bu alanda geliştiremeyen kolluk her zaman suçla ve suçlularla mücadelede reaktif olarak kalacaktır ve proaktif olamayacaktır.

Kurumsal özellikleri içeren bulgular ele alındığında iki farklı yön ortaya çıkmaktadır. Birincisi kolluk teşkilatlarının kurumsal yönü ile ilgili tespitler:

- Sosyal medya araştırmalarına yönelik kurumsal teşkilatlanma istenilen seviyede olmasına rağmen mevcut şartlarda kolluk personelinin görevle alakalı internet erişim seviyesinin istenilen seviyede olmadığı anlaşılmıştır. Asayiş birimlerinde çalışan personelinin özellikle suç araştırmaları için internet ortamından istenilen seviyede yararlanamamaları, bulunduğumuz bilişim ortamında çelişkili bir durumdur. Kurumsal olarak kolluk personeline, özellikle de bilişim suçlarında görevli personele tüm sitelere erişim izninin olması, suçla mücadelede büyük kolaylık sağlayacaktır. Bunun yanında soruşturmaların selameti açısından kolluk personeline kurumsal olmayan IP adresli internet hatlarının temin edilmesi gerekmektedir.

- Kolluk teşkilatlarının kurumsal yönünün diğer bir boyutu ise sosyal medyanın güvenlik kuvvetleri ve halk arasında iki yönlü iletişim sağlayan ve bilgi paylaşımının yapıldığı önemli bir kanal olmasıdır. Kolluk yaptığı faaliyetleri halka sosyal medya aracılığı ile aktararak kendi reklamını yapmalı ve sosyal medya kamusunu genişletmelidir. Böylelikle ihtiyaç duyulduğu anda gündem kurma yetkinliğini kendi elinde bulundurabilecektir. Bu sayede kriz durumlarında veya 
önemli olaylarda halka doğru bilgiler aktarılabilir; provokasyonlar engellenebilir; oluşabilecek bir toplumsal olayın önüne geçilebilir. Bu sağlanamasa bile olayın çapı ve kapsamı daha büyümeden engellenebilir. Ayrıca eylem ve suç öncesi olayların haber alınması, yani ihbar miktarı ve kalitesi artırılabilir. Halkla ilişkiler kurularak toplum polisliği yaratılabilir.

İkincisi sosyal medya firmalarının kurumsal yönü ile ilgili tespitler:

- Sosyal medya firmaları terörist ve aşırılık yanlısı gruplara karşı paylaşım kuralları belirleyerek, terörist faaliyetler için hizmetlerinin kullanılmasının yasaklanması gibi önlemler alabilmektedirler. Paylaşılan içeriklerin gerçek zamanlı olarak izlemenin imkânsızlığı nedeniyle uygulamada bu önlemlerin etkinliği tartışma konusu olabilmektedir.

- Kurumsal tespitlerde en göze çarpanı sosyal medya firma temsilciliklerinin kollukla bilgi paylaşımına yanaşmamasıdır. Sosyal medya firmalarının kurulum merkezleri başka ülkelerde bulunmaktadır. Bu nedenle suç ve terör tanımlamaları bizim ülkemizle birebir eşleşmediği için bilgi paylaşımında sorunlar yaşanmaktadır. Sorunların aşılması için sosyal medya ile ilgili kapsamlı bir mevzuatın hazırlanması gerekmektedir. Terörist grupların veya suç örgütlerinin sosyal medya ortamını kullanmaları ve çocuk pornosu, uyuşturucu, işkence, cinayet gibi bazı suçların sosyal medyada yer alması durumunda, kullanımın kısıtlanması, hesapların dondurulması, bu konulara yönelik yapılan soruşturma veya kovuşturmalarda istenilen bilgilerin ilgili makamlara verilmesine imkân sağlayacak, insanların mahremiyet ve medeni özgürlükler üzerindeki haklarını da teminat altına alacak, hukuki mevzuatın sosyal medya firmaları ile oluşturulması ihtiyacının olduğu tespit edilmiştir. Bu ihtiyaç doğrultusunda hukuksal düzenleme yapılırken dikkat edilecek en önemli hususlardan birisi de evrensel ilkelerden uzaklaşılmaması gerekliliğidir. Aksi durum terör örgütlerinin istismar alanlarını genişletmesine, amaçlarını haklı hale getirmesine ve eleman temininde güçlük çekmemesine olanak tanır.

Teknolojik özellikleri içeren bulgular ele alındığında ise kolluğun elinde bulunan cihaz ve makinaların teknolojik olarak yeni olduğu fakat teknolojik gelişim ivmesi nedeniyle kısa süre sonra teknolojinin gerisinde kalacağ 1 anlaşılmaktadır. Bu ivmenin yakalanabilmesi amacıyla yeni malzeme alımları yapılabilmektedir. Burada tespit edilen ana nokta; yapılan alımlardaki cihazların teknolojisinin ihale alım süreci nedeniyle güncelliğini kaybetmesidir. Problemin 
aşılabilmesi için özellikle bu tarz teknoloji ürünlerinin alımının anlık yapılabilmesine yönelik düzenlemelerin oluşturulması gerekmektedir.

Diğer bir husus ise terör ve suç örgütlerinin iletişim sağlamak amaçlı Deepweb, online oyun programları ve VPN alanlarına kaymaya başlamalarıdır. Gündem oluşturmak, yönlendirme yapmak ve aldatma tedbirleri uygulamak için sosyal medyanın kullanımına devam edileceği, eylem planı ve koordinesi, suç alet ve ürünlerinin pazarlaması için ise bu yeni alanların tercih edileceği anlaşılmaktadır. $\mathrm{Bu}$ nedenle kolluk personeli bu alanlarda kendilerini yetiştirirken proaktif anlayışla terör ve suç örgütlerinin teknolojik yöntem arayışlarını belirleyerek tedbir almalıdır.

Genel anlamda değerlendirme yapılacak olursa; sosyal medyanın sosyal hayata bu kadar katkısı ve faydası olmakla birlikte birey, toplum ve devlet açısından sosyal mühendislik saldırıları, provokasyon, dezenformasyon ve bilgi kirliliği, bağımlılık ve buna bağlı ailevi sorunlar, tehlikeli bilgi paylaşımı ve manipülasyonlar, ekonomik zararlar, kişisel ve özel sırların deşifre olması, özel hayatın gizliliğinin ortadan kalkması gibi önemli tehditleri de içinde barındırmaktadır. Bu tehditlerin ortadan kaldırılabilmesi için sosyal ağlarda kişisel bilgilerin korunması amacıyla kullanıcıların bilgi güvenliği farkındalığının artırılması, korumaya dayalı sosyal ağ modelleri geliştirilmesi önemli hususlardan bazılarıdır. Bunların yanında sosyal medya okur-yazarlığının geliştirilmesi, bilgi kirliliğinin önüne geçilebilmesi için doğru bilgiye erişim alt yapısının güçlendirilmesi, kurum ve kuruluşlarca nitelikli personelin yetiştirilmesi, sosyal medyaya yönelik yasal düzenleme eksikliklerinin giderilmesi büyük önem taşımaktadır.

Sosyal medya ve internetin bu önemine binaen kolluk suç ve terörle mücadelede bu alana daha çok önem vermelidir. Bu önem yeterli ve eğitimli insan gücü planlaması, çağın teknolojik gereklerini uygun bilgisayar yazılımları ve donanımları ve diğer ihtiyaçları da karşılayabilecek maddi kaynakları sağlayarak oluşturulabilir. 


\section{KAYNAKÇA}

Akçay, E.Y. ve Çelenay Ö.E. (2012). Terör ve Medya İlişkisinin 2003 Yılında İstanbul'da Meydana Gelen Saldırılar Örneğiyle İncelenmesi, NEÜ Sosyal Bilimler Enstitüsü Dergisi 2, 183-197.

Altunbaş, F. (2011). Toplum Destekli Polislikte Yeni Bir Boyut: Suç Ve Suçlularla Mücadelede Sosyal Medya Platformları, Suç Önleme Sempozyumu, 361-371

Arıkan, Ü. ve Rençber, H. (2017),Social Media as the Escape Area for İllegality, (31-52). (Edt. Emrah Doğan ve Ercan Geçkin, Current Debates in Public Relations Cultural \& Media Studies, Vol.9, London: Ijopec Publication.

Avşar, Z. (2017), İnternet Çağında Medya, Terör ve Güvenlik, Ankara: TRT Akademi Dergisi, Cilt.2, Say1.3, (116-132).

Aziz, A. (1985). Terör ve Kitle İletişim Araçları, Ankara: BM Türk Derneği Yillığ1.

Barbera, P., Metzger, M., Tucker, J.A. (2003). A Breakout Role for Twitter in the Taksim Square Protests? El Cezire, https://www.aljazeera.com/indepth/ opinion/2013/06/201361212350593971.html, Erişim tarihi: 08.09.2019.

Baykal, N. (2001), Bilgisayar Ağları. (Akt. Beytullah Erol, 2019, Ağ Trafik Özelliklerinin Analizini Yaparak Anormalliklerin Tespit Edilmesi, Yüksek Lisans Tezi), Ankara : Sas Bilişim.

Boyd, D. M. ve Nicole B. E. (2008). "Social Network Sites: Definition, History, and Scholarship", Journal of Computer-Mediated Communication, 13, 210-230.

Briggs, C. (1986). Learning How to Ask: A Sociolinguistic appraisal of the role of the İnterview in Social Science research. Cambridge University Press

Chermark S.M. and Weiss, A. (2005), Maintaining Legitimacy Using External Communication Strategies: An Analysis of Police-Media Relations, Journal of Criminal Justice, 33(5), (501-5012).

Cildan, C. M., Tumuçin, E. H. K. Küçük, E. Albayrak, D. (2012). "Sosyal Medyanın Politik Katılım ve Hareketlerdeki Rolü”, Akademik Bilişim, Erişim: 05.09.2013, ab. org.tr/ab12/bildiri/205.doc

Cybercrimes: Infrastructure Threats from Cyberspace Lawyer, 4 No:2, Cyberspace Law 23. (Akt. Mehmet Özcan, Siber terörizm ve Ulusal Güvenlik: İnternet ve Hukuk, İstanbul: Bilgi Üniversitesi Yayınları, (2002), 309.

Çalı, H.H. ve Altunbaş, F. (2012), Güvenlik Hizmetlerinde Yönetişim Aracı Olarak Sosyal Medya Platformları, Sosyal Bilimler EKEV Akademi Dergisi, Sayı: 50, 2012/1, (1-10). 
Elekoğlu, A.A. (2018), Web 1.0, Web 2.0, Web 3.0, Web 4.0 nedir? Aralarındaki fark nedir? Eğitime katkısı nedir?, https://prezi.com/p/2fxkwakcdgch/web-10web-20-web-30-web-40-nedir-aralarndaki-fark-nedir-egitime-katks-nedir/ Erişim tarihi 02 Şubat 2020

Erdem, T. (2017). Sosyal Medya'da Terör Propagandası: DEAŞ Örneği, Gümüşhane Üniversitesi İletişim Fakültesi Elektronik Dergisi, (728-731).

Erdin, Ç. (2017). Radikal Selefi Örgütlerin Sosyal Medya Kullanımı: IŞi̇D Örneği, Bilge Uluslararası Sosyal Araştırmalar Dergisi, 1(2), (124-130).

Eren, V., Aydın, A., (2014). Sosyal Medyanın Kamuoyu Oluşturmadaki Rolü ve Muhtemel Riskler KMÜ Sosyal ve Ekonomik Araştırmalar Dergisi 16 (Özel Say1 I): 197-205.

Kartal, A. B., (2018). Uluslararası Terörizmin Değişen Yapısı ve Terör Örgütlerinin Sosyal Medyayı Kullanmasi: Suriye'de DAEŞ ve YPG Örneği, Güvenlik Stratejileri, Say1 27, (39-77).

Kazan, H. (2016). Terör Medya İlişkisi ve Medya Terör Haberciliği, Güvenlik Stratejileri Dergisi, Y11 13, Sayı 24, 109-147.

Kernighan, B.W. ve Ritchie, D., (1978). The C Programming Language. Prentice Hall. s. 86, 207. ISBN 0-13-110163-3.

Korkmaz, İ. (2013), Facebook ve Mahremiyet: Görmek ve Gözetle(n)mek, Yalova Üniversitesi Sosyal Bilimler Dergisi, Vol.3, Sayı. 5, (107-122).

Kurum, M. (2017). Terörist Örgütlerin Güvenli Ortamları ve PKK. Ankara, Nobel Bilimsel Eserler.

Marcu, M. ve Bălteanu, C. (2014). Social Media-A Real Source Of Proliferation Of International Terrorism, Annales Universitatis Apulensis Series Oeconomica, 16(1), (162-169).

Mostchall, M. and Cao, L. (2002), An Analysis of the Public Relations Role of the Police Inquiry Information Officer, Sage Journal: Police Querterly, 5(2), (152180).

Özçetin, D. ve Özçetin, B. (2015), Polis ve Sosyal Medya: Türkiye'de İl Emniyet Müdürlüklerinin Twitter Kullanımı, Uluslararası Kıbrıs Üniversitesi, Folklor/Edebiyat Dergisi, Lefkoşe, Cilt:21, Sayı:83, (19-48).

Özkır, Y., (2018). Fransa'da Basın Özğürlüğü Sar1 Yelek'e Takıldı, https://www.aa.com.tr/tr/analiz-haber/fransada-basin-ozgurlugu-sari-yeleketakildi/1338759 Erişim tarihi 08 Eylül 2019 
Patton, M.Q. (1987). How to use qualitative methods in evaluation, Newbury Park, CA: Sage

Pesen, M., (2017). Sosyal Medyanın Arap Baharı'ndaki Rolünün Bilimsel Kanıtı, www.e-siber.com Erişim Tarihi 08 Eylül 2019.

Steward C.J. ve Cash, W.B. (1985). Interviewing: Principles and Practices (4. Baskı), (Akt. Ali Yıldırım ve Hasan Şimşek), Dubuque, 10: Wn.C. Brown Pub

Yalçınkaya, İ. A. (2008). Medya-Terörizm İlişkisi, Yayınlanmamış Yüksek Lisans Tezi, Karadeniz Teknik Üniversitesi, Sosyal Bilimler Enstitüsü, Trabzon.

Yıldırım, A. ve Şimşek, H. (2018). Sosyal Bilimlerde Nitel Araştırma Yöntemleri, Ankara: Seçkin Yayınları.

Weimann, G. (2004). Special Report, How Modern Terrorism Uses the Internet, United States Institute of Peace, Washington.

Wilkinson, P. (1997). "The Media and Terrorism: A Reassessment", Terrorism and Political Violence, Vol. 9, No.2, 51-64.

Wilkinson, P. (2002). Terör ve Terörizm: Kavramlar, Özellikler ve Tipoloji, Silinen Yüzler Karşısında Terör (s. 142-163), Cemal Güzel (der.), Ankara: Ayraç Yayınları.

http://www.blog.isimtescil.net/vpn-nedir-ne-ise-yarar/ Erişim tarihi 14 Eylül 2019 http://www.ebizmba.com/articles/social-networking-websites Erişim tarihi 14 Eylül 2019

http://wearesocial.com/global-digital-report-2019 Erişim tarihi 12 Eylül

https://www.google.com/search?q=global+web+index+flagship+report+2019\&oq= global+web+index+flagship+report+2019\&aqs=chrome..69i57.40840j1j7\&sour ceid=chrome\&ie=UTF-8 Erişim tarihi 11 Eylül 2019

http://www.onedio.com/haber/hashtag-nedir-nasil-olmalidir--308322 Erişim tarihi 02 Şubat 2020

https://www.haberturk.com/ekonomi/teknoloji/haber/1255438-satista-sira-twitterageldi Erişim tarihi 02 Şubat 2020

https://sosyalmedya.co/facebook-ortaklar/ Erişim tarihi 02 Şubat 2020

https://www.bilimcag.com/nedir/web-1-0-2-0-3-0-nedirfarklari-nelerdir/ Erişim tarihi 02 Şubat 2020 
